\title{
LAKÁSJELLEMZŐK NYÍREGYHÁZÁN 2008-2010
}

\author{
SZOBOSZLAi KATALiN
}

\begin{abstract}
Within the field of housing and their characteristics a negative tendency can be seen with a very modest increase in the number of houses and flats, while the quantity and quality of rented flats in 2008 and in 2010 remained the same. As for household equipment, the supply with telecommunication devices such as broadband Internet increased by $10 \%$ in two years' time. Income has an effect on the payment of expenses. Those who regard their financial situation as worse than it was in 2008 spend less on basic needs such as consumer goods, recreation and social relations. In addition they also have little or almost nothing to be saved. As a workaround to the payment problems only a fraction of people with bad financial situation relies on the support of local government.
\end{abstract}

Keywords: number of houses and flats, quality of rented flats, payment of expenses, payment problems

DOI: $10.19055 / \mathrm{ams} .2012 .3 / 3 / 5$

\section{BEVEZETÉS}

A „Nyíregyháza életminősége - háztartáspanel” vizsgálat (továbbiakban: panel vizsgálat) lakásokra vonatkozó elemzésekor számításba kellett vennem a lakásállomány stabilitását városunkban. A tény, miszerint nagyon kicsi növekedés tapasztalható a lakás állományban, nem hozott érdemi változást a két évvel ezelöttihez képest a lakásokra vonatkozó adatokban. A lakónépesség és a lakásállomány változásainak bemutatásához az elmúlt évekről szóló KSH adatokat, időnként a 2001. évi népszámlálási adatokat használom fel. A lakásjellemzök leírása föként a 2008-as adatokból épül fel, és ahol kimutatható eltérés, ott jelezni fogom a 2010-es adatokat az összehasonlítás érdekében. Ahhoz, hogy a lakásjellemzők ne pusztán épületekről szóljanak, belevettem az elemzésbe a lakásban élés emberi tényezőit, úgymint a megélhetés szubjektív megítélését, a jelentkező kiadásokat és a problémákat. Úgy vélem, hogy a 2012-ben esedékes adatfelvételnél több lehetőség nyílik az összehasonlításra, mivel rendelkezésre állnak majd a 2011. évi népszámlálási adatok, illetve a három adatfelvétel hat évet ölel át, ami a jövőben tágabb teret enged az elemzésnek. 


\section{A LAKÓNÉPESSÉG ÉS A LAKÁSOK SZÁMÁNAK ALAKULÁSA NYÍREGYHÁZÁN}

Nyíregyháza a lakónépesség adatai alapján az ország hetedik legnépesebb városa. A város népessége a 1970-es évektől kezdve növekszik, amiben jelentős szerepe van az urbanizáció mellett a közép-és felsőoktatási intézményeknek, a munkahelyek bővülésének és a lakosság életkörülményeinek javulását jelentő lakásépítéseknek. (1. táblázat)

\begin{tabular}{|c|c|c|c|c|c|}
\hline Év & $\begin{array}{c}\text { Lakónépesség } \\
\text { száma az év végén (fö) } \\
\text { (a népszámlálás végleges } \\
\text { adataiból továbbvezetett } \\
\text { adat) }\end{array}$ & $\begin{array}{c}\text { Állandó } \\
\text { népesség } \\
\text { száma } \\
(\text { fó) }\end{array}$ & $\begin{array}{c}\text { Lakások } \\
\text { száma } \\
(\mathrm{db})\end{array}$ & $\begin{array}{c}\text { Épített } \\
\text { lakások } \\
\text { száma } \\
(\mathrm{db})\end{array}$ & $\begin{array}{c}\text { Lakásállomány } \\
\text { növekedés } \\
\text { mértéke az } \\
\text { elöző } \\
\text { évhez (\%) }\end{array}$ \\
\hline 2005 & 115.954 & 118.273 & 48.000 & 1.063 & nincs adat \\
\hline 2006 & 116.298 & 118.456 & 48.713 & 767 & $1,5 \%$ \\
\hline 2007 & 116.874 & 118.580 & 49.515 & 899 & $1,6 \%$ \\
\hline 2008 & 117.595 & 118.874 & 50.296 & 781 & $1,5 \%$ \\
\hline 2009 & 117.832 & 119.179 & 50.784 & 515 & $1,01 \%$ \\
\hline 2010 & 117.852 & 119.094 & 51.057 & 273 & $0,53 \%$ \\
\hline
\end{tabular}

1. táblázat - Lakónépesség és lakások számának változása 2005-2010. Forrás: KSH, városadatok, 2005-2010.

A lakónépesség számában enyhe növekedés tapasztalható 2005-2008. között Nyíregyházán, azonban az utolsó két év adatai a növekedés megtorpanását mutatják. A lakások számának alakulásáról az adatok alapján elmondható, hogy a gazdasági válság hatásai ezen a területen is jelentkeznek, hiszen amíg 2009 előtt évente 1,5\%-os emelkedéssel számolhattunk, addig 2009 után előbb 1,01\% majd 0,53\% -ra csökkent a lakásépítés mértéke. Az újonnan épített lakások a magántulajdonban lévő lakások arányát erösítik az önkormányzatihoz képest, ami csöppet sem enyhíti a bérlakásra várók, illetve a bérlakást váltani szándékozók helyzetét. (2. táblázat)

Összevetve a 1-2. táblázat adatait a lakásállomány száma növekedést mutat, 6.912 darab lakás gyarapítja a lakásállományt 2001-2010. között, a lakások több mint kilenctizede magántulajdonban van, az önkormányzati rész kevesebb, mint $4 \%$, és töredék az egyéb lakástípus aránya. (3. táblázat)

A 2001. évi népszámlálási adatok alapján a lakásállomány több mint $80 \%$-ában maga a tulajdonos lakik, míg a bérleti, szolgálati jogcímen lakott lakások aránya 7,5\% a városban. A tulajdonosi lakások erőteljes jelenléte mellett drámaian alacsony a bérlakások száma városunkban. A megyei jogú városokban 5,1\% az önkormányzati bérlakások aránya (Hegedűs, és KSH, 2009.). A 2001. évi népszámlálási adatok alapján 7,5\% a bérleti és szolgálati lakások aránya Nyíregyházán. Ez az arány picit emelkedhetett az 
elmúlt évtizedben, az un. „fecskelakások” építésével és a Huszár telep szélén könnyüszerkezetes új lakások bérbeadásával. A bérlakások komfortja nagy eltéréseket mutat, a szegénytelepek nyomorúságos lakásaitól (Orosi út mellet a Keleti lakótelep, Huszár telep) a lakótelep összkomfortjáig (Jósavárosban, Örökösföldön) nagyok a különbségek.

\begin{tabular}{|c|c|c|c|c|c|}
\hline \multicolumn{6}{|c|}{ Lakásállomány (lakás és lakott üdülö összesen), 2001. $44145 \mathrm{db}$; ebből } \\
\hline \multicolumn{2}{|c|}{ Természetes személy tulajdona } & \multicolumn{3}{|c|}{ Önkormányzati tulajdonú } & \multicolumn{3}{|c|}{ Egyéb } \\
\hline 42124 & $95,4 \%$ & 1677 & $3,7 \%$ & 271 & $0,6 \%$ \\
\hline
\end{tabular}

2. táblázat - A lakások tulajdona Nyíregyházán 2001.

Forrás: KSH, népszámlálási adatok, http://www.nepszamlalas.hu

\begin{tabular}{|c|c|c|c|c|c|}
\hline \multicolumn{5}{|c|}{ Használat jogcíme, 2001. } \\
\hline \multicolumn{2}{|c|}{ Tulajdonosi } & \multicolumn{2}{|c|}{ Bérleti, szolgálati } & \multicolumn{2}{c|}{ Egyéb } \\
\hline $37280(\mathrm{db})$ & $84.5 \%$ & $3308(\mathrm{db})$ & $7.5 \%$ & $187(\mathrm{db})$ & $0.4 \%$ \\
\hline
\end{tabular}

3. táblázat - A lakásállomány használati jogcíme Nyíregyházán.

Forrás: KSH, népszámlálási adatok, http://www.nepszamlalas.hu

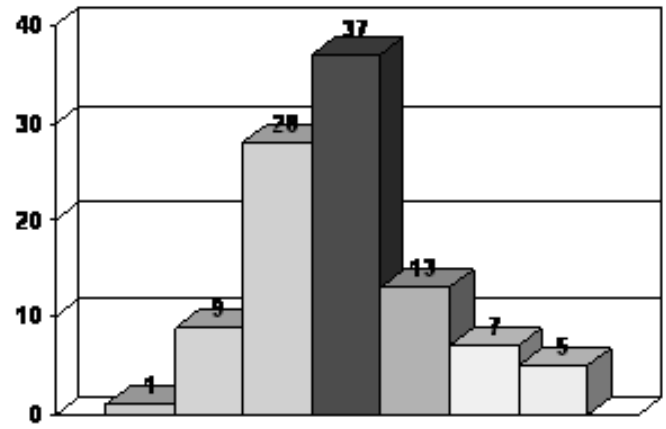

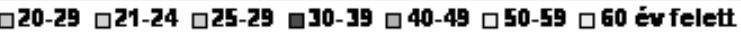

1. ábra - Bérlakást igénylők korcsoportonként, 2004 (százalékban). Forrás: Előterjesztés a Közgyülés számára Nyíregyháza Megyei Jogú Város Lakáskoncepciójában megfogalmazott feladatok aktualizálására. 1362/40/2004.II.

http://www.nyirhalo.hu/index.php?option=content\&task=view\&id=3103 
A lakások tulajdonosi jellemzői hasonlóak az országos képhez. Az önkormányzatai bérlakások privatizációja lezajlott az ország minden nagyvárosában a 1990-es évtized első felében. Nyíregyházán az ezredfordulón mindösszesen a lakásállomány 3,7\%-a volt az önkormányzat kezelésében. A bérlakásállomány drasztikus csökkenése leginkább a létminimum szintjén vagy az alatt élö társadalmi csoportok, és a fiatalok lakáshoz jutását nehezíti meg. (1. ábra)

Nyíregyházán bérlakás igénnyel többnyire a fiatal, 40 év alatti gyerekes családok jelentkeznek, akik a piaci áron kínált bérlemény helyett önkormányzati bérlakásban élnének. A szabad választás mellett a kényszer is megjelenik ezen lakáshasználat mögött azok a lakosoknál, akiknél lakbér vagy közüzemi díjhátralék okán nem tartható meg elözö lakásuk, és önkormányzati szükséglakásokban kapnak elhelyezést szegényes körülmények között.

\section{A LAKÓNÉPESSÉG MOZGÁSA ÉS KÖTŐDÉSE A VÁROSHOZ}

2008-ban azt találtuk, hogy a városlakók 82\%-a két évnél korábban költözött jelenlegi lakásába, és az emberek közel 12\%-a azon a helyen él, ahová született. Az adatok arra engednek következtetni, hogy családi állapot alapján a házasoknál és a kapcsolatban élőknél jellemző nagyobb arányban a lakásváltás, míg legkevésbé az özvegyeknél. 2010-ben, az első adatban nincs változás, hanem pici csökkenés érzékelhető a születéskor „elrendeltetett” lakást tekintve, ez az arány 11\%-ra változott. A különbség adódhat a minta összetételéböl éppúgy, mint halálozásból.

A lakónépesség mozgása városon belül jellemzőbb, mint a beköltözés. 2008-ban azt találtuk, hogy városlakók 77\%-a költözött korábban más városrészre, 2010-ben növekedés tapasztalható, ez az arány $80 \%$. A városon kívülröl jóval kevesebb a költözés. 2008-ban megyebeli településről 18\% költözött városunkba, az ország más területeiről és külföldről csupán 5\%. 2010-ben 15\%-ra mérséklődött a beköltözés a megyéböl, míg az ország más területéről maradt az 5\%-os arány. Életkort tekintve a lakásváltók 2/3-a a 30-64 év közötti korosztályhoz tartozik. A városból kiköltözők az agglomeráció településeit részesítik elönybe.

Az adatokból megállapítható, hogy a költözéseknél inkább a belső mozgás jellemzőbb, mint a kívülről befelé történő áramlás. A lakosok belső mozgásából arra következtethetünk, hogy a kedvezőbb és komfortosabb életkörülmények miatt változtatnak lakóhelyet, figyelembe véve a belső területekre jellemző környezeti feltételeket. A városi életforma mellett a megyeszékhely vonzó hatása érvényesül akkor, amikor munkahelyváltás miatt költöznek a megye valamelyik településéről Nyíregyházára. A megyehatártól távolabbi területről, akár külföldről beköltöző lakost elvétve találtunk. Úgy látszik, hogy a város betelepülöket vonzó hatása kevésbé érvényesül más, az ország határon belüli és azon túli területekről. 


\section{A LAKÁSOK ALAPTERÜLETE ÉS LAKÁSBAN ÉLŐK}

A lakások alapterületében szembetűnő változások nem tapasztalhatók, hiszen a lakásállomány bővülése csupán 1,5\%-os 2008 és 2010 között. (2. ábra)

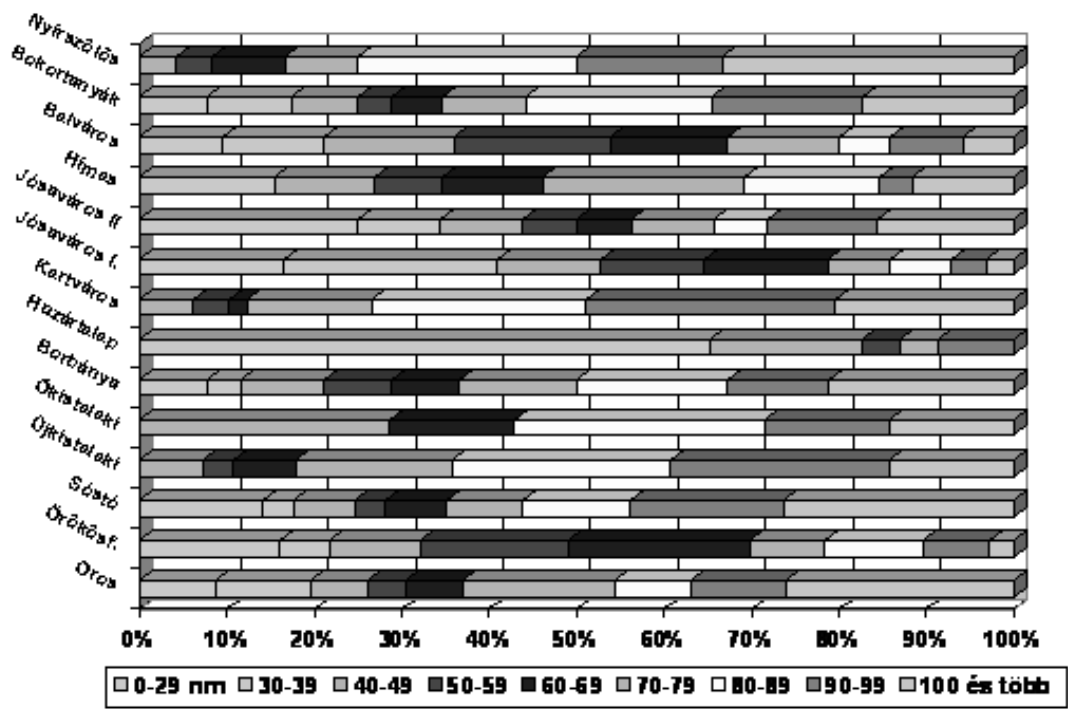

2. ábra - Lakások alapterülete a város egyes területein 2008-2010. Forrás: Háztartáspanel 2010.

A lakások egynegyede 100 m2-t meghaladó alapterületủ lakás, és kicsivel több, mint egytizede 40 m2-nél alacsonyabb lakóteret foglal magában. Jellemzően Oroson, Kertvárosban,Sóstón, Borbányán és Nyírszölösön a lakások felének minimális alapterülete $80 \mathrm{~m} 2$, és a lakások egyharmadában az alapterület a $100 \mathrm{~m} 2$-t meghaladja. Ezzel szemben Jósaváros lakótelepi részén a lakások felénél az alapterület kevesebb, mint $50 \mathrm{~m} 2$. A legrosszabb a helyzet a Huszár telepen, ahol a lakások kétharmadában kevesebb, mint $40 \mathrm{~m} 2$-en élnek a családok. (3. ábra)

A gyerekes háztartások élnek a legkisebb alapterületü lakásokban, a családok egyharmada egy gyereket és kétharmaduk három gyereket nevel. Ezek a legfeljebb $29 \mathrm{~m} 2$-es lakások két felnőtt és egy (kettő és három) gyermek számára nem jelentenek elégséges életteret, hiszen nem különülnek el a gyermeki és felnőtt élet szinterei egymástól, és hiányzik a játékhoz, a tanuláshoz és a társas együttléthez szükséges hely. Szembeötlő adat, miszerint a 30-39 m2 alapterületü lakások 60\%-ában egyszülős családok élnek, és további két alapterület kategóriában 40-40\%-ban találjuk meg őket. A kétgyermekes párok jel- 
lemzően a 70 m2 vagy annál nagyobb alapterületü lakásokban élnek, míg a háromgyerekesek egy része a $80 \mathrm{~m} 2$ vagy annál nagyobb alapterületü lakásokban lakik.

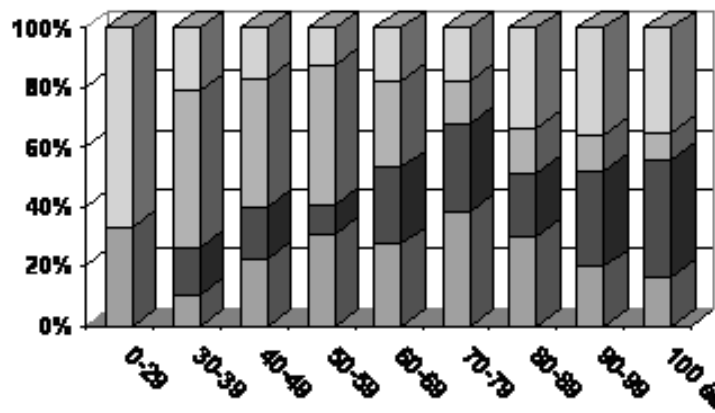

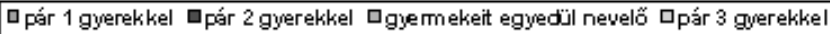

3. ábra - Gyerekes háztartások és alapterület (négyzetméter) 2008-2010. Forrás: saját adatfelvétel.

\section{A LAKÁSOK KOMFORTFOKOZATA ÉS FELSZERELTSÉGE}

A városban található lakások $90 \%$-a összkomfortosnak tekinthető, vagyis a lakásban található fürdőszoba, WC, melegvíz és központi fütés. A lakások minőségét árnyalja az a modell, amivel megvizsgáltuk, hogy nyolc, a lakás komfortfokozatának minőségét jelző változó közül mennyi található meg a lakásokban. Ezek a változók: WC a lakásban, fürdőszoba, hideg víz a lakásban, meleg víz a lakásban, vezetékes gáz, központi fütés, szeparált konyha, terasz. ${ }^{1}$ (4. táblázat)

\begin{tabular}{|l|l|}
\hline Minőség & $\%$ \\
\hline legalább 5 elem & 2,8 \\
\hline legalább 6 elem & 9,2 \\
\hline legalább 7 elem & 34,3 \\
\hline mind a 8 elem & 53,6 \\
\hline Összesen & 100 \\
\hline
\end{tabular}

4. táblázat - A lakások minősége komfortosság alapján 2008-ban (százalékban). Forrás: Háztartáspanel 2010.

1 Takács Péter modell számítása alapján. 
Az adatokból jól látszik, hogy a városban a lakások $88 \%$-ában legalább hét elem és 97\%-ában hat elem található meg.. Ez alapján elmondhatjuk, hogy a lakások minősége a kor színvonalának megfelelő a városban. A lakások megközelítően 3\%-ánál legfeljebb öt elem lelhető fel. Ezek a komfortos vagy ennél alacsonyabb minőséget mutató lakások. Ezekből a lakásokból a gáz, a központi fütés, a szeparált konyha, a terasz közül egy vagy több elem hiányzik. A legrosszabb a lakások komfortja a város szegénytelepein, az önkormányzat bérlakásaiban. A Huszár telepen 2008 elött néhány lakóház rekonstrukciójára sort kerített az önkormányzat, azonban a lakóépületek többsége minimális komforttal rendelkezik a Huszár telepen és komfort nélküliek a Keleti lakótelepen. 2010-ben a lakások komfortja nagyjából ugyanaz, pici eltolódás tapasztalható felfelé. Valószínüsíthető, hogy az újonnan épült lakások miatt érezhető pozitív változás.

\section{A LAKÁSBAN ÉLŐK JÖVEDELMÉNEK SZUBJEKTÍV TÉNYEZÖI}

A lakásfenntartás olyan költségekkel jár, amelyek megterhelik a háztartásokat. A KSH lakásviszonyokról készített elemzése mutat rá arra, hogy a kiadások a legalsó jövedelmi ötödbe tartozóknál jelentkeznek a legnagyobb arányban, náluk a lakásfenntartás költsége a jövedelem $30 \%$-át is eléri. Relatíve legjobb helyzetben a legfelsö ötödbe tartozók vannak, akiknél a jövedelem 16\%-át teszik ki ezek a kiadások Magyarországon. Számottevő azoknak a háztatásoknak a száma, ahol a 25\%-os, elfogadhatatlannak minösített nemzetközi küszöböt meghaladó lakáskiadások jelentkeznek. (KSH, 2005) Ugyancsak a KSH adat világít rá arra, hogy ezek a költségek régiónként és városonként eltérést mutatnak. Az Észak-alföldi Régióban a megyeszékhelyeken átlagosan 18\%-ot tesz ki a háztartás jövedelméböl a lakásfenntartásra fordított összeg, amely adat megegyezik az országos átlaggal. (KSH, 2005) Valószínüsíthető, hogy az elmúlt években ez az arány emelkedett, ami nehezen vállalható vagy nem kifizethető költséggé vált a szegényeknél, és átrendezi a középosztály lakásra fordított kiadásait is.

A panel vizsgálat 2010. évi kérdései közül bevettem az elemzésbe azokat a témaköröket, amelyek a jövedelmi helyzet megítéléséröl és a lakásköltségek kifizetésének problémáiról szólnak. A kiadások elemzése előtt essen néhány szó a bevételt jelentő jövedelmekről.

A háztartások havi nettó jövedelme a városi átlagot tekintve kicsit több mint 177 ezer forint. Az egyes városrészekben jól érzékelhetők a különbségek, a legkevesebb pénzböl a Huszár telepen élnek, míg a legtöbb bevételt Jósaváros kertvárosi területén lakók tudnak magukénak. (Fábián-Takács, 2011.) Milyen forrásból van jövedelme jellemzően a városlakóknak? (4. ábra)

A jövedelem típusokat tekintve két kiugró értéket találunk, a fóálású alkalmazotti bérjövedelem és a nyugdíj, amely kategóriák biztos jövedelmet jelentenek, szemben a különféle szociális transzferjövedelmekkel, a gyerekek után járó támogatásokkal, időszakos fizetésekkel a közmunka és alkalmi munka világában vagy a vállalkozói jöve delemmel, amit igen nehéz valódi értékén megállapítani.

A háztartások havi jövedelméböl kellene az együtt élők szükségleteit kielégíteni, ezekhez a kiadásokhoz tartoznak a lakással, lakhatással kapcsolatos ráfordítások is. Több 
vagy kevesebb jutott a kiadásokra az elmúlt két évben? Vajon hogyan értékelik jövedelmüket, megélhetésüket a városlakók 2010-ben 2009-hez és 2008-hoz képest? (5. ábra)

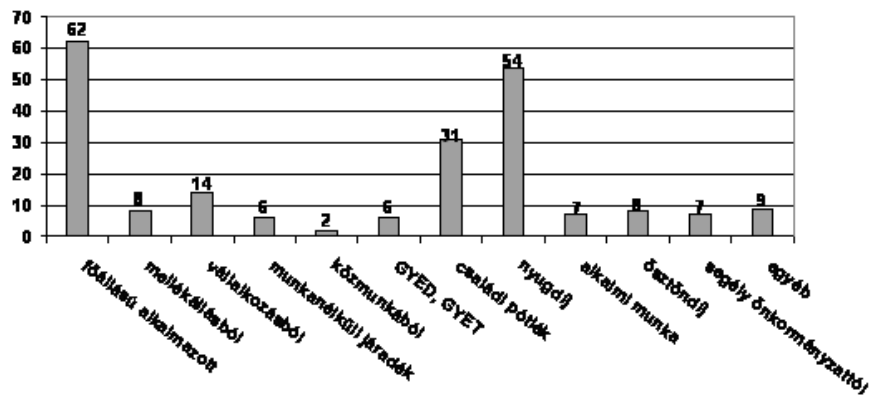

4. ábra - Jövedelem forrása 2010-ben (százalékban). Forrás: Háztartáspanel 2010.

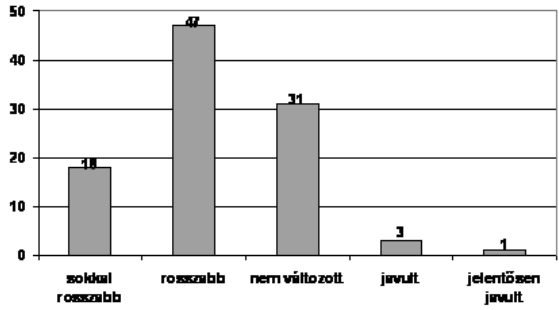

5. ábra - Havi jövedelem szubjektív megítélése az előző évhez /évekhez képest 2010-ben (\%-ban). Forrás: Háztartáspanel 2010.

Az adatok alátámasztják az elöbbi feltételezést, hiszen a városlakók közel egyötöde sokkal rosszabbnak gondolja jelenlegi jövedelmét az előző év(ek)hez képest, és további $47 \%$ rosszabbnak ítéli meg mostani helyzetét a korábbinál. Érdemes odafigyelni azokra is, akik szerint nem változott a jövedelmük, ez az egyharmad a stabilnak tekinthető jövedelem kategóriákhoz tartozók egy részét jelenti (alkalmazott, nyugdíjas). A jövedelmi helyzet pozitív megítélése mindösszesen 4\%-ot mutat, ami az elmúlt két évben a pénzügyi-gazdasági válság és társadalmi hatásainak (pl. munkanélküliség növekedése, hitelválság, munkabérek és nyugdíjak reálértéken sem növekedtek) ismeretében nem is annyira meglepö. (6. ábra)

A jövedelmi helyzet szubjektív megítélésén nem változtatnak a gyerekek azok esetében, akik sokkal rosszabbnak ítélik meg a jövedelmüket. Azokban a háztartásokban, ahol gyerekek élnek a városlakók picit jobbnak látják helyzetüket ott, ahol csak általában rosszabb, nem változott vagy éppenséggel javult a jövedelmi helyzet. A gyerekes 
családok esetében eltérés látszik a jövedelem objektív adatai és a szubjektív megítélés között. „A gyermeket nevelő háztartások nagyobb valószínüséggel tartoznak a kedvezötlenebb jövedelmü csoportokba, mint a gyermektelen háztartások." (Fábián-Takács, 2011/1.számú ábra) A látszólagos ellentmondás feloldását segítheti az a megközelítés, miszerint a gyerekes családokban a jövedelmi helyzet optimistább megítélése a gyerekekhez kapcsolható pozitív gondolkodásban, a támogatások kiszámíthatóságában kereshető.

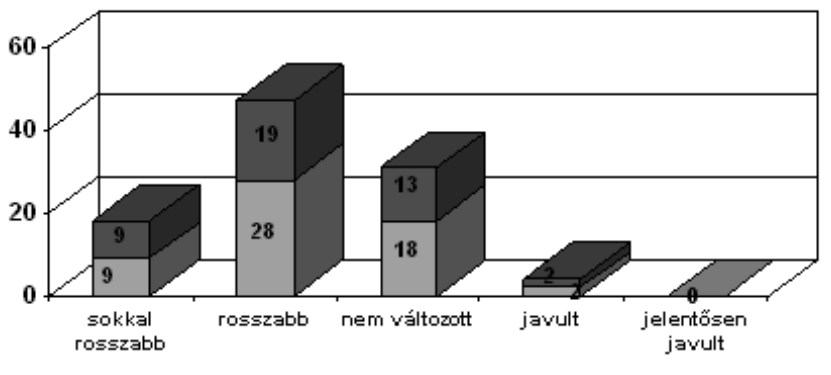

口gyermek nélkül agyermekkel

6. ábra - A jövedelmi helyzet megítélése gyermekes és gyermek nélküli háztartásokban, 2010-ben (\%-ban). Forrás: Háztartáspanel 2010.

A jövedelmi helyzet szubjektív megítélésének ismerete fontos abból a szempontból, hogyan viszonyulnak a megkérdezettek a kiadásaik finanszírozásához, mit engedhetnek meg maguknak, és miröl kell(ene) lemondaniuk. (7. ábra)

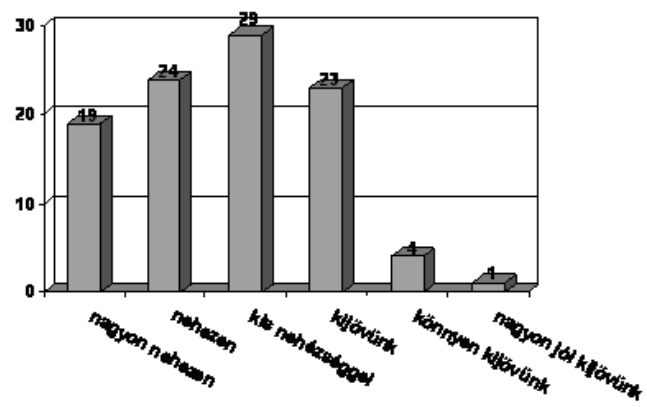

口havi jövedelemböl megélni

7. ábra - A havi jövedelemből való megélhetés szubjektív megítélése 2010-ben (\%-ban). Forrás: Háztartáspanel 2010.

Az 5. és 7. ábrák összevetéséből kitünik, hogy hasonló arányban fordulnak elő azok, 
akik sokkal rosszabbnak ítélték meg helyzetüket és azok, akik nagyon nehezen élnek meg a jövedelmükböl. Mindkét változónál közel $20 \%$ arányban találjuk azokat, akik igen alacsony jövedelemből élnek és helyzetük lényegesen rosszabbra fordult az elmúlt két évben. Ha hozzávesszük azokat, akik nehezen élnek meg a bevételeikből, akkor azt látjuk, hogy a városlakók 43\%-ának komoly problémát jelent a megélhetés. Megközelítően $30 \%$ azoknak az aránya, akiknél kisebb gondot jelent a jövedelmet jól beosztani, és $23 \%$ mondja, hogy valahogyan kijön a havi jövedelméböl. Itt is fontos látni, hogy a felső kategóriákba kevesen helyezték magukat, csupán 5\% képes könnyen és gond nélkül megélni jövedelméböl. Ezek a problémák a lakásfenntartás költségeinek kifizetésében is jelentkezhetnek, hiszen más felmérések eredményéből tudható, hogy az emberek az élelmiszer után a lakásfenntartásra fordítanak jelentős összegeket a havi jövedelemböl. (KSH, 2005)

A lakáshoz és a megélhetéshez tartozó kiadások fizetése általában komoly terhet jelent a háztartásoknak. A panelvizsgálat adatai arra engednek következtetni, hogy azoknál jelentkeznek a kiadásokban problémák, akik nagyon nehezen élnek meg a jövedelmükből. Az idetartozók közül minden második esetben elöfordult, hogy elmaradt valaminek a kifizetése. (8. ábra)

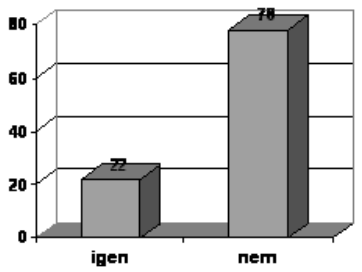

口fizetéxi probléma fenn äll-e

8. ábra - Került-e olyan helyzetbe, hogy nem tudott valamit kifizetni? (\%-ban). Forrás: Háztartáspanel 2010 .

A nyíregyháziak egyötöde került korábban olyan helyzetbe, hogy kiadásait nem tudta megnyugtató módon rendezni. A kérdőív alapján nem tudjuk pontosan megválaszolni, hogy milyen költségeket nem tudnak kifizetni a háztartásokban. A következő adatfelvételnél lehetne ezeket a költségeket és a hátralék mértékét vizsgálni.

Néhány évvel ezelött a megye lakosságának szociális helyzetét és egészségi állapotát vizsgáló kutatás adatai alapján mégis elmondható, hogy a háztartásokban élők a ki adásokat tekintve az otthonon kívüli szórakozásról és nyaralásról a háztartások kilenctizedében lemondanak. (Filepné-Fónai-Fábián, 2006:58)

Szembetűnő a 8. sz. ábrán a pozitív választ adók 78\%-os aránya, ők azok, akik nem jeleztek gondot a kiadásoknál, és alighanem képesek megvásárolni mindazt, amire szükségük van. (9. ábra)

A kiadások kifizetése azoknál a városlakóknál jelent problémát, akiknél valamilyen 
mértékben megjelenik a jövedelem beosztásának a gondja. A legnehezebb helyzetben lévők képesek a legkevésbé fedezni kiadásaikat meglévő jövedelmükből, és csak kicsit jobb a helyzet azoknál, akik nehezen vagy kis nehézséggel tudják beosztani pénzüket.

A 8. sz. ábrán látható adatok rávilágítottak arra, hogy a városlakók egyötöde került már olyan helyzetbe, hogy valamit nem tudott kifizetni a jövedelméböl, és négyötöde valahogyan mégis megoldja. Képesek-e takarékoskodni a helyiek, amire nehezebb időkben támaszkodhatnak? (10. ábra)

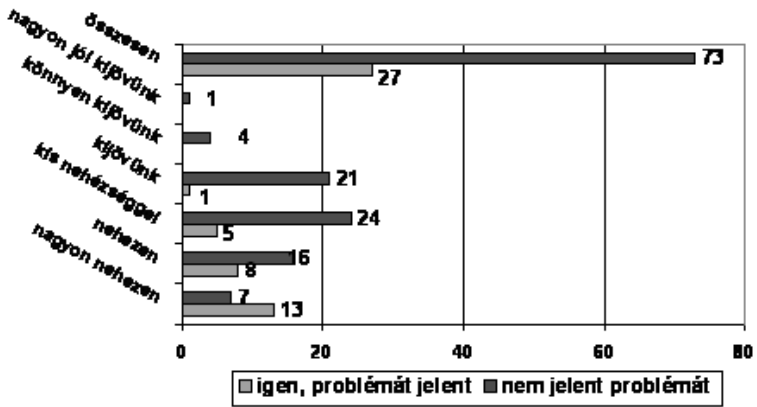

9. ábra - Jelent-e Önöknek problémát a kiadások finanszírozása? (2010. \%-ban). Forrás: Háztartáspanel 2010.

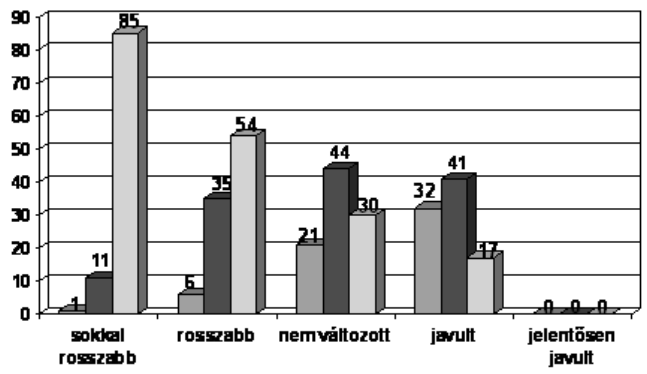

$\square$ igen, tud félretenni $\square$ keves et $\square$ nem tud takarékoskodni

10. ábra - Jövedelem szubjektív megítélése és takarékoskodás 2010ben (\%-ban). Forrás: Háztartáspanel 2010.

A fenti ábrán azt látjuk, hogy megtakarítás azoknál keletkezett 2010-ben, akiknek javult vagy nem változott a jövedelmi helyzete az elmúlt két évben. ${ }^{2}$ Ebbe a két kategóriába tartozók háromnegyede rendelkezik valamennyi megtakarítással. Egy kevés tarta-

2 A top kategóriában csak válaszhiányt találtam erre a kérdésre. 
lék azoknak is van, akik rosszabbnak ítélték meg helyzetüket az előző évekhez képest, de náluk már látszik a tartalékok hiánya is. A tőlük rosszabb helyzetben lévőknél eltünik a megtakarítás és ennek hiányában kénytelenek fedezni kiadásaikat. A takarékoskodás biztonságot és kiszámíthatóságot jelent az emberek életében, és olyan erőforrás, amit hamar mozgósíthatnak a kiadások fedezésére. Általános helyzetkép Magyarországon, hogy az emberek felélik esetleges megtakarításaikat, ami megnehezíti, gyakran lehetetlenné teszi kiadásaik finanszírozását, és meggátolja tartalékok képzését. (11. ábra)

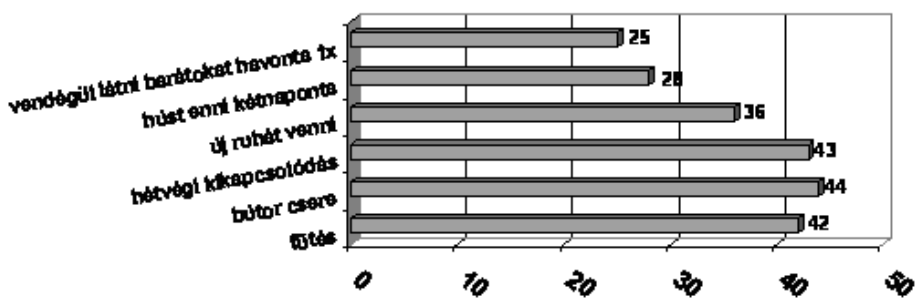

11. ábra - Mi jelent problémát a kiadásokban, 2010-ben (\%-ban). Forrás: Háztartáspanel 2010.

A jövedelmi helyzet megítélése, a tartalékok hiányosságai afelé mutatnak, hogy bizonyos szükségletek kielégítése problémát jelenthet a városlakóknak. Az alapszükségleteknél a meleg lakáshoz szükséges a fütési költségek kifizetése, ami a lakosok $42 \%$-nál jelent problémát. Ez a relatíve magas arány a szolgáltatóknál jelentkező díjhátralékokban mutatkozik meg. „Nyiregyházán a közüzemi cégek kintlévősége meghaladja az 550 millió forintot" - olvasható a háztartási adósságkezeléssel foglalkozó Szocio East Egyesület közleményében. ${ }^{3}$ A nem fizetőkkel szemben egy rövid ideig elnéző az áram és gázszolgáltató, aztán tartós hátralék esetén a szolgáltatásból történő kikapcsolással válaszol. A távfütésnél kicsit jobb a helyzet, hiszen egy hátralékkal rendelkező fogyasztót nem lehet lekapcsolni a rendszerről. Ugyancsak alapszükségletnek tekinthető az életkorhoz, aktivitáshoz, egészséghez nélkülözhetetlen élelmiszerhez történő hozzájutás. Hetente kétszer húst enni valóban a minimális szükségletet jelzi, ami a vizsgálat adatai alapján a városlakók 28\%-ánál gondot jelent. Ezek az emberek nem jutnak hozzá megfelelö összetételü és tápértékü élelmiszerhez, ami betegség előidézője lehet. Új ruhára és új bútorra a városlakók több mint egyharmada nem áldoz pénzt, és olyan kiadásokat sem tudnak fedezni, amelyek a pihenéshez és a társas együttléthez szükségesek. ${ }^{4} \mathrm{Az}$ otthonon kívüli hétvégi pihenésre a városlakók közel fele mondott nemet, a barátokkal való havonta egyszeri találkozásra egynegyedük nem tud pénzt költeni.

3 Forrás: http://www.szocioeast.hu/page.php?16

4 A Szabolcs-Szatmár-Bereg megyei kutatás adatai is megerősítik ezt a megállapítást. 
Kérdésként vetődik fel, hogy a kiadások könnyítéséhez, vajon kérnek-e segítséget a városlakók az önkormányzattól. (12. ábra)

A városlakók 15\%-a említette, hogy fordult segítségért a Szociális Osztályhoz, és jellemzően azok, akik rosszabbnak vagy sokkal rosszabbnak ítélik meg jövedelmi helyzetüket 2010-ben a két évvel korábbihoz képest. Valószínüleg ök azok, akiknek talán sohasem volt megtakarításuk, vagy tartalékaik kimerültek, és az önkormányzattól várnak támogatást a kiadásokra. Az adatokból kitünik, hogy a városlakók 84\%-a saját bevallása szerint nem kért segítséget a helyhatóságtól, ők vélhetően más módon kezelik kiadásaikat. Ebben az adatban a szemérmesség éppúgy jelen lehet, mint a segélyezéssel és a segélyezettekkel szembeni elutasítás.

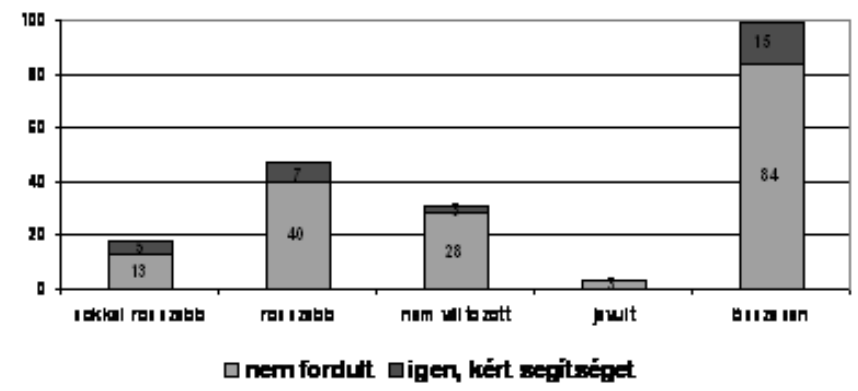

12. ábra - Fordult-e a Szociális Osztályhoz segítségért? (2010. \%ban). Forrás: Háztartáspanel 2010.

\section{ÖSSZEFOGLALÁS}

A lakóhely és a lakásjellemzők területén lényeges változásokról nem tudtunk beszámolni 2008-2010. összevetésében. Negatív tendenciának minősíthető a lakásállomány bővülésének igen szerény mértékü emelkedése, a bérlakások változatlan mennyisége és minősége. Pozitív fejlemény a lakásfelszerelést tekintve a telekommunikációs eszközök használata és köztük a szélessávú Internettel való ellátottság 10\%-os emelkedése két év alatt. Ez a növekmény a jövőben tovább fejlődhet ismerve a szolgáltatók közötti versenyt és új eszközök megjelenését ezen a területen. A városlakók kiadásainak finanszírozására leginkább jövedelmük van hatással. Mindazok, akik rosszabbnak ítélik meg szubjektíven saját helyzetüket 2010-ben, mint amilyen az 2008-ban volt, kevesebbet költenek alapszükségleteket kielégítő fogyasztási cikkekre, pihenésre és társas kapcsolatokra. És ugyancsak ők azok, akik keveset vagy szinte semmit nem képesek megtakarítani jövedelmükből. Áthidaló megoldásként a kifizetési problémáknál a kedvezötlen anyagi helyzetben lévők töredékénél jön szóba az önkormányzat támogatása. 


\section{IRODALOM}

1. Fábián Gergely - Takács Péter: A jövedelmi egyenlőtlenségek változásai és szegénység (Kézirat, 2011.)

2. Filepné Nagy É.-Fónai M.-Fábián G.(2006.): A Szabolcs-Szatmár-Bereg megyei népesség szociális helyzete és egészségi állapota In: Etnikai szegénység, etnikai egészségi állapot? Fónai Mihály-Pénzes Mariann-Vitál Attila szerk. Krúdy Könyvkiadó-Szocio East Egyesületp. 43-74.

3. Hegedủs József és mtsai(2009.): Lakhatási szükségletek Magyarországon. Városkutatás Kft. Letöltési hely: www.mut.hu/?module=news\&action=getfile\&fid $=114874$

4. Lakásviszonyok az ezredfordulón. KSH, Budapest, 2005.

5. Letöltési hely: http://mek.niif.hu/06900/06979/06979.pdf

6. Szoboszlai K.-Takács P. (2010): Lakóhely és lakásjellemzők Nyíregyházán. Szabolcs-Szatmár-Beregi Szemle, 2010/3. p. 343-554. 